\section{REVIEW ON THE DEVELOPMENT OF FUEL CELLS AND ITS FUTURE PROSPECTS}

Thareny Ravichandrana,b, Juhana Jaafara,b*, Hamid Ilbeygic, Mochammad Purwantod

aAdvanced Membrane Technology Research Centre (AMTEC), Universiti Teknologi Malaysia, 81310 UTM Johor Bahru, Johor, Malaysia

bSchool of Chemical and Energy Engineering, Faculty of Engineering, Universiti Teknologi Malaysia, 81310 UTM Johor Bahru, Johor, Malaysia

cFuture Industries Institute, University of South Australia Building $X$, Mawson Lakes Campus, Mawson Lakes SA 5095, Adelaide SA 5001

dKampus Institute Teknologi Kalimantan Karang Joang, Jalan Soekarno Hatta KM 15 Karang Joang, Balikpapan 76127, Kalimantan Timur, Indonesia
Article history

Received

31 December 2020

Received in revised form

29 March 2021

Accepted

1 April 2021

Published online

22 April 2021

*Corresponding author juhana@petroleum.utm.my

\section{Graphical abstract}

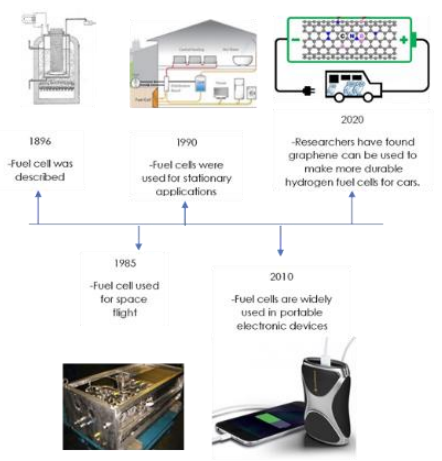

\begin{abstract}
Fossil fuels are unsustainable energy storage medium with pollution problems. With the limitation of fossil fuels, fuel cells, which are known as effective electrochemical converters, has attracted much attention. Present review paper provides a complete information on fuel cell technology and history which includes competing technologies, current status of research-and-development and its future direction. Fuel cell plays an important role in stationary applications from 1990s till now due to its efficiency upon reducing emissions.
\end{abstract}

Keywords: Fuel cells, renewable energy, fuel cell applications, sustainable source, technologies

\begin{abstract}
Abstrak
Bahan api fosil adalah medium penyimpanan tenaga yang tidak berkekalan dan mempunyai masalah pencemaran. Dengan keterbatasan bahan api fosil, sel bahan api, yang dikenali sebagai penukar elektrokimia berkesan semakin dikaji oleh ahli sains. Makalah ini mengulas maklumat komprehensif mengenai sains sel bahan api dan sejarahnya yang merangkumi teknologi bersaing, status terkini penyelidikan dan pengembangan dan sasaran masa depan. Sel bahan api memainkan peranan penting dalam aplikasi pegun dari tahun 1990-an hingga sekarang kerana dapat mengurangkan pelepasan.

Kata kunci: Sel bahan api; tenaga diperbaharui; aplikasi sel bahan api; tenaga berkekalan; teknologi
\end{abstract}




\subsection{INTRODUCTION}

Natural resources can be categorized into renewable and non-renewable [68]. Renewable resources or clean energy includes wind, hydro, tidal, geothermal, biomass, and solar energy [69]. They produce lower emissions of carbon dioxide which can reduce the dependency on fossil fuels. Natural renewable resources are the predominant energy source that has been used throughout history. Biomass is the primary energy source that has been used widely in the developing country up to date. Non-renewable resources are those resources that are no longer available once the existing resources are exhausted. Fossil fuels are considered non-renewable although they renew themselves in a few millions of years. Humans extract them in various forms such as in gas, liquid, or solid which is then converted for their use, mainly related to energy [70-71]. According to World Wide Fund [1], $90 \%$ of the world's energy consumption is supported by fossil fuels. About every 20 years, the consumption of fossil fuels nearly doubles. As fossil resources are depleting, the world population is becoming concerned each day. Governments all over the world are considering alternative and sustainable sources of power. Fuel cell technology is gaining attention worldwide due to its renewable nature [2]. Owing to internal combustion-free operation, fuel cell technology is noise-free and low maintenance. With only water as the primary byproduct of its exhaust stream, the fuel cell is a zeroemission technology.

Sir William Grove invented fuel cell in 1838. Later, in 1982, Francis Thomas Bacon created gas diffusion electrode. O.K Dartyan experimented with high and low alkaline hydrogen cell. During 1950s, fuel cell was being developed for space exploration. Many advancements in technology have led to the practical usage of fuel cell. Applications of fuel cell includes macro (e.g. bus) and micro scale (e.g. laptop). In United States, in 2019, the fuel cell market was estimated at over USD 3.5 billion, with annual installations expected to cross 400 thousand units by 2026 [74]. Fuel cell process comprises of converting chemical energy to electrical energy [72]. Typically, electrochemical reactions take place at electrodes with different charges named anode and cathode. The electrochemical reaction produces electric current when gaseous/liquid are fed as fuels to the electrode (anode) compartment, simultaneously, an oxidant is fed continuously to the cathode compartment. Figure 1 shows the basic mechanism of energy conversion [73]. Fuel cell have some disadvantages such as degradation and/or malfunction of specific components [3].

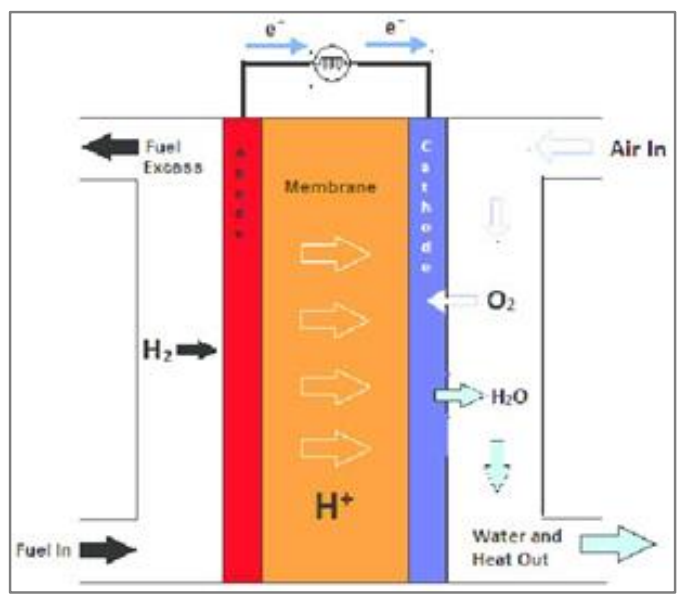

Figure 1 Basic mechanism of energy conversion [73]

There are variety of fuel cells which are being developed. There are different categorizations of fuel cells such as according to type of electrolyte, a combination of a type of fuel and oxidant, temperature of operation, whether the fuel is processed outside (external reforming) or inside. However, the widely use categorization of fuel cells are mainly according to its type of electrolyte. Under this categorization, the fuel cell can be divided into 5 , namely: proton exchange membrane (polymer) electrolyte fuel cell (PEMFC), alkaline fuel cell (AFC), solid oxide fuel cell (SOFC), molten carbonate fuel cell (MCFC), and phosphoric acid fuel cell (PAFC).

Fuel cells are used in military because of the high power and lighter in comparison to traditional portable applications $[5,6]$. The manufacturing of a portable fuel cells is costly. To manufacture 50,000 fuel cell stacks for portable system, $\$ 166 \mathrm{~kW} / \mathrm{e}$ to $\$ 5,387$ $\mathrm{kW} / \mathrm{e}$ is needed for a $250 \mathrm{~kW} / \mathrm{e}$ system, per year [7].

The fuel cell provides energy for future applications. It is now being used to replace the internal combustions engines that undesirably for environmental nurturing. The history of fuel cells can be found in the last two centuries. But its development and progress do not publish. Therefore, this review paper aims to show advancements of fuel cells in various sectors and future prospects of them.

\subsection{CURRENT APPLICATIONS}

Fuel cells have a large variety of approach in a number of markets. Its applications are ranging from small scale power supply such as gadgets to a larger level power supply such as power plants. Fuel cell applications are shown from the year 2014 to 2018 (Figure 2) [4]. 


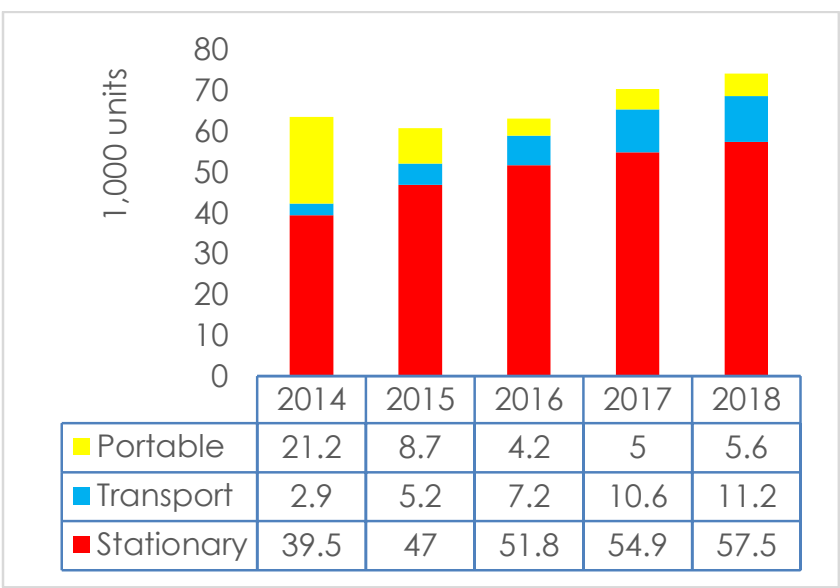

Figure 2 Fuel cell applications by category [4]

The graph shows the units of fuel cell used different applications. Number of fuel cells used for stationary is dominant in the range of years. Usage in portable has decreased noticeably. While, fuel cell applications in transport have been slightly increasing in the years.

\subsection{Portable Applications}

Power for portable fuel cells ranges from 5 to $500 \mathrm{~W}$ and the power range could reach $\mathrm{kW}$-level up to some of the demanding portable electronics. Portable fuel cells such as cellular phones, laptops, and battery chargers can be moved around and used for various activities. On the other hand, stationary fuel cells are immoveable. The energy density of a typical fuel cell is 5-10 fold higher than that of rechargeable batteries. This makes fuel cell to be a more favorable option for portable devices. For instance, direct methanol fuel cells (DMFCs), reformed methanol fuel cells (RMFCs), and PEMFCs are being used for portable military. Table 1 shows the contrast between fuel cells and its portable technology opponents. By referring to the table, it is clear that fuel cells have high effectiveness and capacity.

\subsection{Stationary Applications}

Residential, industrial, and commercial sectors have high demands for fuel cells for both grid-assisted power supply and grid-independent fuel cells. Gridindependent fuel cell also known as stand-alone fuel cell. Table 2 shows the contrast between fuel cells and its stationary technology opponents. Based on the table, it is important to note that the fuel cells have high effectiveness and influencing factors in the stationary sector. Selamogullari et al. [9] has demonstrated that the light load efficiency can be increased by using an insulated gate bipolar transistor-metal oxide semiconductor field-effect transistor (IGBT-MOSFET) switch combination in a halfbridge inverter topology. Hydrogen usage can be reduced by utilizing the new inverter design in standalone operations. To connect the fuel cell-based Distributed Generation (DG) system to a utility grid, output voltage, real and reactive power flow, phase, and frequency of the inverter has to be modified in order to be able to control between DG and grid [1012].

Nelson et al. [13] demonstrated an energy storage system using a combination of a fuel cell stack, an electrolyzer, and a hydrogen storage tank. This configuration was used to compare a traditional hybrid energy system with battery storage. The study showed that an existing method is economical than using the conventional fuel cell.

Karakoulidis et al. [14] has discussed the advantages of standalone-based fuel cell systems in terms of technical and economical using simulations. The result indicates that diesel generators and batteries by hydrogen technologies decreased fossil fuel dependency

\subsubsection{Large-scale Power Generation}

Phosphoric acid fuel cell (PAFC) technology is playing a major role in the market. Since the 1970s, more than 500 PAFC power plants have been installed and tested around the world [15]. Molten carbonate fuel cell (MCFC), solid oxide fuel cell (SOFC), and polymer electrolyte membrane fuel cell (PEMFC) units have been established too. However, MCFC, SOFC, and PEMFC are accepted mostly in the market due to its cost which is lower than phosphoric acid. The PAFC is least preferable compared to other types of fuel cells due to the lack of progress towards the sustainable price. To provide higher efficiencies at higher power, MCFCs are used.

MCFCs are bound to be adopted at a higher power of above $250 \mathrm{~kW}$ because of their higher efficiencies. Electrochemical reaction increases when current that can be obtained at a given voltage [16].

The major advantage of a fuel cell in large- and small-scale power generation is significantly more variable as compared to transportation and portable sectors. A few processes of industries produce a lot of waste biogas and it can be used with fuel cells to create power with ease.

\subsubsection{Residential and Small Stationary Power Generation}

Fuel cells that are used in residential have units of between 1 and $10 \mathrm{~kW}$. Few studies suggest that a fuel cell should be able to provide electricity for the whole house [17]. Meanwhile, others suggest that fuel cells should only provide baseload. Although PEMFC and SOFC units are popular, more companies are working on PEMFC. Europe, North America, and Southeast Asia are the three main regions active in fuel cell development [18]. Fuel cells require significant development work in obtaining uninterruptible power supplies and to have the durability of $>5$ years which can encounter the real requirements of the world customers. 
Table 1 Contrast among fuel cells and their portable technology opponents [8]

\begin{tabular}{|c|c|c|c|c|}
\hline $\begin{array}{l}\text { Portable } \\
\text { technology }\end{array}$ & $\begin{array}{l}\text { Gravimetric energy } \\
\text { density (Wh/kg) }\end{array}$ & $\begin{array}{l}\text { Volumetric energy } \\
\text { density (Wh/L) }\end{array}$ & Power density(W/kg) & $\begin{array}{l}\text { Capital cost } \\
\text { (S/kWh) }\end{array}$ \\
\hline DMFC & $>1000$ & $700-1000$ & $100-200$ & 200 \\
\hline Lead-acid battery & $20-50$ & $50-100$ & $150-300$ & 70 \\
\hline Nickel-cadmium battery & $40-60$ & $75-150$ & $150-200$ & 300 \\
\hline Nickel-metal hydride battery & $60-100$ & $100-250$ & $200-300$ & $300-500$ \\
\hline Lithium-ion battery & $100-160$ & $200-300$ & $200-400$ & $200-700$ \\
\hline Flywheel & $50-400$ & 200 & $200-400$ & $400-800$ \\
\hline Ultracapacitor & 10 & 10 & $500-10000$ & 20000 \\
\hline
\end{tabular}

Table 2 Contrast among fuel cells and their stationary technology opponents [8]

\begin{tabular}{|c|c|c|c|c|c|}
\hline Stationary power & Power level (MW) & Efficiency (\%) & Lifetime (years) & Capital cost $(\mathrm{S} / \mathrm{kW})$ & Capacity factor (\%) \\
\hline Phosphoric acid fuel cell & $0.2-10$ & $30-45$ & $5-20$ & 1500 & Up to 95 \\
\hline MCFC/ags turbine hybrid & $0.1-100$ & $55-65$ & $5-20$ & 1000 & Up to 95 \\
\hline SOFC/gas turbine hybrid & $0.1-100$ & $55-65$ & $5-20$ & 1000 & Up to 95 \\
\hline Steam cycle (coal) & $10-1000$ & $33-40$ & $>20$ & $1300-2000$ & $60-90$ \\
\hline $\begin{array}{l}\text { Combine gas turbine } \\
\text { cycle (natural gas) }\end{array}$ & $50-1000$ & $45-60$ & $>20$ & $500-1000$ & Up to 95 \\
\hline Microturbine & $0.01-0.5$ & $15-30$ & $5-20$ & $800-1500$ & $80-95$ \\
\hline Hydroelectric & $0.1-2000$ & $65-90$ & $>40$ & $1500-3500$ & $40-50$ \\
\hline Solar photovoltaic & $0.001-1$ & $10-15$ & $15-25$ & $2000-4000$ & $<25$ \\
\hline
\end{tabular}




\subsection{Transportation Applications}

The transportation industry aims to reduce the harmful emissions without compromising efficiencies. This is mainly because each year, the industry of transportation is accountable for $17 \%$ of the worldwide greenhouse gas (GHG) outflows [20]. Fuel cells offer near-zero harmful emissions and enhanced efficiencies than conventional internal combustion engines [21]. Fuel cells are being used in vehicles for the past few years [22]. Fuel cell voltage is stepped up by direct current-direct current (DC-DC) converters to the main DC bus voltage [23]. Since power management between battery and motor is the main problem with the fuel cell vehicle, hybridization is required with the energy storage unit [24].

The focus of automobile manufacturers is to determine some issues on the mass generation of FCVs. By 2030, it is expected that FCVs could replace traditional cars $[25,26]$.

Toyota Motor Corporation (TMC) started the fuel cell hybridization vehicles in 1992. In June 2005, TOYOTA had the first vehicle fueled by the fuel cell and acquire FCHV (Fuel Cell Hybrid Vehicle) certification [27].

\subsubsection{Auxiliary Power Units (APUs)}

PEMFCs, DMFCs, and SOFCs are being developed for APU applications. Fossils such as methanol, LPG, natural gas, gasoline, and diesel are possible fuels to develop fuel cells. Vehicles such as airplanes require fuel cells that operate at high-temperature such as MCFCs and SOFCs.

Non-propulsive power is produced by the onboard APU in vehicles. Unlike portable applications, the APUs are built in the vehicle. Heavy-duty trucks [28, 29]; leisure yachts, planes, and cars [30] are successful markets of APUs because of their high electrical energy demand [31-33]. By using a fuel cell as an onboard APUs, it could decrease NOx emissions up to $95 \%$, particulate matter- 10 emissions by up to $65 \%$, and $\mathrm{CO}_{2}$ emissions by more than $60 \%$ [34].

\subsubsection{Light Traction Vehicles (LTVs)}

Some examples of light traction vehicles (LTVs) are scooters, airport tugs, and motorbikes. Generally, the highest positive use of the fuel cell is forklifts. Forklifts are extensively used in the warehousing and distribution industry, with nearly 2.5 million forklifts in operation in North America [35]. Conventional forklifts use rechargeable lead-acid batteries or combustion engines that use diesel, gasoline, LPG, compressed natural gas, or propane.

Approximately 1300 fuel cell-powered forklifts are functioning in the US market up to date [36]. Fuel cell forklifts normally use PEMFCs or DMFCs. Examples of LTVs are personal wheelchairs [37] and light carts [38]. Table 3 below shows the comparison of the conventional forklifts and fuel cell-based forklifts [8].

\subsubsection{Light-duty Fuel Cell Electric Vehicles (L-FCEVs)}

Light-duty fuel cell electric vehicles (L-FCEVs) provide fuel cell-based energy to the propulsion system. LFCEVs provide noise-free operation, more efficient energy usage [39] compared to the current enginebased vehicles. L-FCEVs has a longer range, better acceptance of cold weather, refueling time, and lower weight compared to light-duty battery electric vehicles (L-BEVs).

The main common parts of an L-FCEV include highpressure hydrogen storage tanks (stores hydrogen), fuel cell stack (generates electricity), supplemental Lithium-ion battery (stores electricity), power drive unit governs electrical flow), and an electric drive motor (propels vehicle).

L-FCEVs are not used commercially because of its lifecycle costings and drawbacks in its durability in fuel cell stack. The most commonly used fuel cell in L-FCEVs is hydrogen PEMFCs. Honda, Nissan, and other major vehicle producers are in the effort of utilizing L-FCEVs as the main propulsion system using the fuel cell system connected to an electric motor [40].

L-BEVs are the main competition for L-FCEVs with nickel-metal-hydride (NiMH) batteries being used in the L-BEVs market. In the future, NiMH will be replaced by lithium-ion (Li-ion) batteries in L-BEVs. L-BEVs and LFCEVs have pros and cons that are highly dependent on the main energy source (biomass, renewable, or fossil), energy conversion chain (e.g., transport, hydrogen production, and storage mechanisms), and design requirements (driving range, maximum speed, or passenger capacity) [8].

Campanari et al. [41] found a temporary result for light-duty hybrid electric vehicles (L-HEVs) by using both batteries and fuel cells to merge their strengths. When biomass or natural gas are used as an energy source for a distance more than $160 \mathrm{~km}$, Thomas [42] found L-FCEV has some advantages over L-BEV by referring to the mass of the vehicle, the volume of storage, GHG emissions, and well-to-wheel energy efficiency. Compared to other technologies, vehicles that use batteries, corn ethanol, hydrogen fuel cells, and cellulosic ethanol release less GHG. Due to constraints of hydrogen storage, hydrogen fuel that is needed to operate an L-FCEV is usually generated offboard [43].

\subsubsection{Heavy-duty Fuel Cell Electric Vehicles (H- FCEVs)}

Heavy-duty fuel cell electric vehicles (H-FCEVs) uses fuel cell for the electric propulsion system include buses, vans, heavy-duty trucks, etc. In 2012, Western Europe had 30 fuel cell buses while the United States had 25 [44]. Fuel cell electric buses (FCEBs) release very low emissions compared to conventional buses that use diesel. This makes FCEBs become the publics' favorite. 
Other vehicles that are powered by fuel cells are different compared to buses. This is because infrastructural requirements of hydrogen for buses is simple due to the fixed routes. In addition, these buses have flexible mass and size limitations for hydrogen storing system in comparison to traditional buses.

Few governments who have deployed FCEBs are the US, Canada, Japan, Australia and China. There are a few programs that are being carried out in different countries. For example, Sustainable Transport Energy Program (STEP) in Australia [45], the Clean Urban Transport for Europe (CUTE) and HyFLEET: CUTE project in Europe [46], Hydrogen Fuel Cell Demonstration Project in Canada, Urban-Route Buses Trial Project [47] in China and Zero Emission Bay Area (ZEBA) demonstration [48] and the Brazilian Fuel Cell Bus Project in California [49]. Figure 3 shows few important components in a FCEB [50].
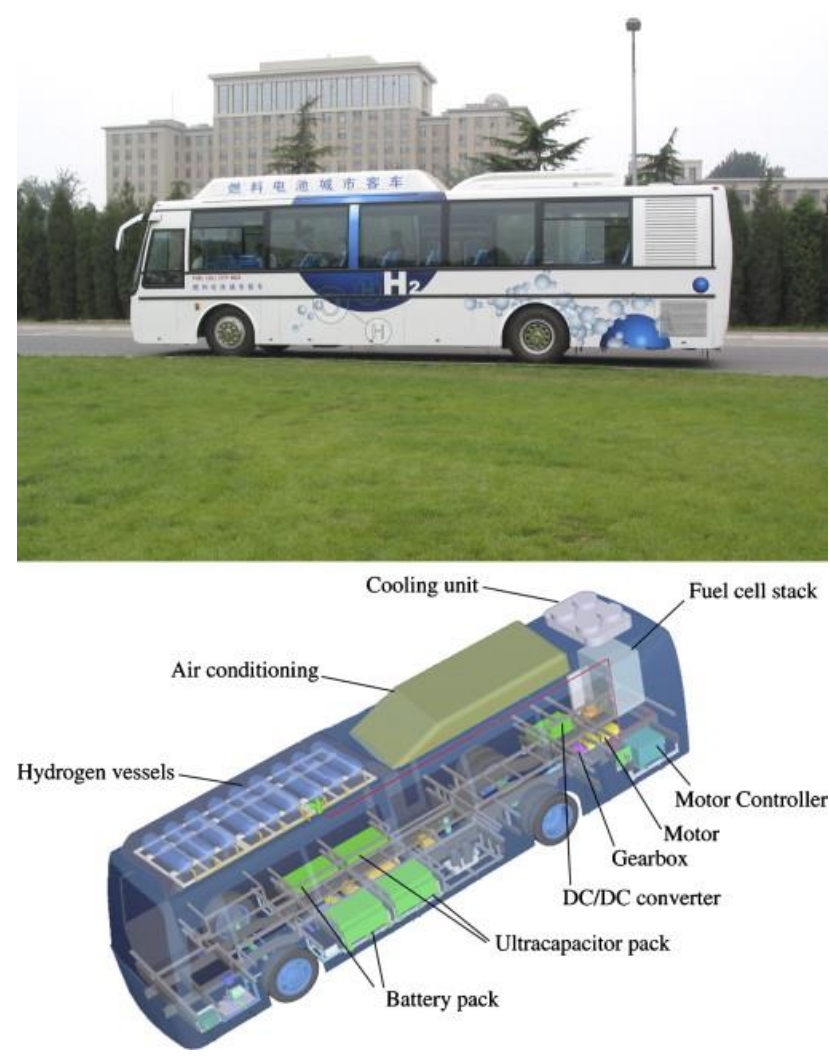

Figure 3 Components in a FCEB

The main components in FCEBs are auxiliary components, transmission, electrical motor, fuel supply unit, fuel cells, air condition and hydrogen tank which are mostly similar to L-FCEVs. PAFCs and PEMFCs are the most frequently utilized types for the stack and high-voltage batteries used for regenerative braking energy recovery and an improved dynamic response. The under-developed fuel cell technologies and the absence of mass production causing FCEBs to become unable to compete in terms of economy with traditional buses and other competing novel innovations. This is more obvious for FCEBs than LFCEVs because of the increasing demonstration programs' number and the endeavours by bus and fuel cell developers such as Hydrogenics, Ballard, and Daimler AG. A few noteworthy, milestones and demonstrations have been accomplished for $\mathrm{H}$ FCEVs.

Table 3 Comparison of the conventional forklifts and fuel cell-based forklifts [8]

\begin{tabular}{|c|c|}
\hline Conventional forklifts & Fuel cell-based forklifts \\
\hline Harmful emission & $\begin{array}{l}\text { Less-harmful emission than } \\
\text { conventional }\end{array}$ \\
\hline $\begin{array}{l}\text { Most of the forklifts } \\
\text { operates outdoors only }\end{array}$ & $\begin{array}{l}\text { Can operate indoors or } \\
\text { outdoors }\end{array}$ \\
\hline $\begin{array}{l}\text { Larger space for battery } \\
\text { changing and charging }\end{array}$ & $\begin{array}{l}\text { Less space for a refueling } \\
\text { station }\end{array}$ \\
\hline $\begin{array}{l}\text { Longer time to recharge } \\
\text { or changing batteries }\end{array}$ & Less time to refuel \\
\hline $\begin{array}{l}\text { Sensitive to the ambient } \\
\text { temperature }\end{array}$ & $\begin{array}{l}\text { Low sensitivity to the } \\
\text { ambient temperature }\end{array}$ \\
\hline Shorter operational cycles & Longer operational cycles \\
\hline Less operational efficiency & $\begin{array}{l}\text { More operational } \\
\text { efficiency }\end{array}$ \\
\hline
\end{tabular}

In Germany, a hybrid waste disposal truck had been developed. The truck uses a hybrid diesel engine and a fuel cell system. The fuel cell system in the truck can use to collect, manage and dispose of waste. Meanwhile, the use of a diesel engine is for propulsion. Guo et al. [51] designed and used a power system for rail systems which will meet the locomotive's power demand with high effectiveness. The power system is a hybrid switcher locomotive that uses a SOFC power plant, ultracapacitors and lead-acid batteries. Miller et al. [52], on the other hand, found that a fuel cell yard switcher locomotive is better than using a hybrid fuel cell design. There is a low potential for recovery of regenerative braking energy and hybrid designs would be difficult.

\subsubsection{Aerial Propulsion}

Fuel cells are used in space and aeronautics sectors in small unmanned aerial vehicles (UAVs). UAVs are usually used for observation purposes. UAVs are widely preferred in the military sectors. PEMFCs are usually ideal for powering UAVs. Static operation and low heat emission are the benefits of UAVs over the internal combustion engine. One of the major advantages of fuel cells that makes it a good candidate to be able to use in a small-scale application is that its modularity. Bradley et al. [53] determined five different potential small-scale UAV propulsion systems. Kim et al. [54] concluded that for a long flight, UAVs is more efficient than battery- and combustion-based battery. The space industry is among the earliest to implement the fuel cell. In Japan, the fuel cell-powered high-altitude balloon was successfully tested [55). During the 1960s, NASA 
utilized PEMFCs and AFCs in their operated space explorations. Fuel cells are widely being used in space explorations because of the numerous advantages. The most attractive advantage is water being generated as a by-product of the electrochemical reactions where in space, air, water, and food are important $[56,57]$.

\subsubsection{Marine Propulsion}

APUs on-board boats and yachts are the most common fuel cell that is being used in the current marine propulsion market. There is a promising future for the fuel cell market in marine propulsion that still exists in marine transports such as submarines, boats, underwater vehicles, and cargo ships. For marine vehicles, low release, high productivity, and immobile operation are the benefits of fuel cells. On the other hand, problems related to reliability, wave resistance, life-span, and resilience to the salt present in the sea air need to be reviewed.

In the marine fuel cell market, PEMFCs, SOFCs, and MCFCs hold the most promising future. The first-ever certified hybrid PEMFCs/lead-gel batteries system for APU and propulsion were introduced and put in service in Germany in 2003. As compared to the conventional diesel-based ship, this ship has twice the efficiency. Adding to that, in 2009, a hydrogen fuel cell boat was established in Austria. The boat has a fourpart propulsion system which are photovoltaic panels, an electrolyzer, a high-pressure hydrogen storage system, and a fuel cell. Water is broken down into hydrogen and oxygen in an electrolyzer using solar energy. In order to propel the boat, hydrogen is fueled into the fuel cell system.

In order to apply fuel cell system in marine environment, first, there are several challenges to overcome. For example, high power demand of the ships and salt water tolerance [58].

\subsection{Micro Power}

The fuel cell can be applied in mobile appliances such as phones and laptops, which help to increase battery life [60]. Direct methanol battery will opt for mobile appliances. Fuel cell is popular in telecommunication systems [61]. Some telecommunication companies such as Sony [62] have shown that fuel cells can enhance telecommunication equipment. As an example, they proved that equivalent sized phones that are powered with fuel cell has twice the capacity of a lithium battery. Fuel cell-powered laptops can operate 5 hours without recharging.

Telecommunication companies are using fuel cell energy as a back-up supply. In Indonesia, 400 fuel cell supplies have been set up. In Caribbean, 60 fuel cells have been set up. These actions are in order to provide green energy and to obtain advantages from the fuel cell system [61].

\subsection{FUTURE TARGETS}

The key targets of the fuel cell industry and solutions in achieving more advanced fuel cells that meet future targets are as follows:

- Encourage academic communities and industrial personnel to do research and development.

- Reduce the degradation of MEA.

Surprisingly, potential reason that cause corrosion of cathode catalysts layers are discovered and may be attenuate by ever-changing the planning of anode catalyst. By as well as further chemical element evolution reaction practicality into the catalyst layer, anodes may be protected from corrosion by cell reversal. Through such changes, Petch et al. [63] have exhibited large enhancements to the steadiness and sturdiness of MEA. Specifically, vital enhancements within the tolerance of cell reversal of MEAs with novel anodes are described.

- Electrolyte material that can conduct and stable over a wide range of temperature and humidity.

To produce stable electrolytes from rare earth elements doping has been done [64-66].

- No or little catalysts PGM loading.

A kinetic model of autocatalytic degradation for PGM-free catalysts was proposed by Shao et al. [67] They observed a quicker current density drop at 0.84 $\checkmark$ if a lower cell voltage of 0.7 or $0.4 \mathrm{~V}$ was first used in their study. This observation was caused by the effect of $\mathrm{H}_{2} \mathrm{O}_{2}$ /radicals on catalyst stability.

- Membrane and catalyst that can tolerate impurities.

For hydrogen separation, catalytic membrane reactors were studied to identify hydrogen separation rates and separation factors because of its ability to be able to compare to those of Pd-based membranes. The membrane had a high resilience toward $\mathrm{CO}_{2}$ and $\mathrm{H}_{2} \mathrm{~S}$ impurities [68].

- Design a bipolar plate with the reduced weight

To decrease the weight and size of a PEMFC, a new plan was used [69]. As compared to the metallic bipolar plate, graphite bipolar plates were used in the conventional types of PEMFCs. This is because graphite bipolar plates are weightier and larger than the latter.

The as-proposed novel cooling design can decrease the size of the cell by up to $75 \%$, in addition, to efficiently cool the PEMFC than the graphite bipolar plate. 


\subsection{CONCLUSION}

The overview paper presents an updated record of the fuel cell, specially specializing in its competing technology and its future targets. The latest records from enterprise and academia were used as a reference for the paper. Although there are boundaries, the enterprise will have the ability to conquer those and make certain the gasoline cells may be commercialized into the industrial marketplace.

The advancement of fuel cells has largely increased over the previous few years with an increment in intrigued through governments and a higher profile in terms of public intrigued. A supply chain is starting to improvement with a number of corporations working on the large-scale manufacturing of fuel cells and its components. A few have definitely opened factories dedicated entirely to fuel cells. But, the maximum brilliant highlight of the company is the kind of companies involved. Whether they see fuel cells as an opportunity for upcoming development or as a chance to their modern-day commerce, numerous researches have decided the case for fuel cells to be correctly compelling to begin making a funding with.

\section{Acknowledgement}

The authors express gratitude to the Malaysian Ministry of Education (MOE) and Universiti Teknologi Malaysia for research grant and facility.

\section{References}

[1] World Wild Fund. 2020. Natural Resources. Retrieved from: https://wwf.panda.org/knowledge_hub/teacher_resourc es/webfieldtrips/natural_resources/

[2] Kinjyo, Y., A. Bungo, Y. Atsushi, S. Tomonobu, F. Toshihisa. and Chul. H. K. 2012. Optimal Operation of Smart Grid with Fuel Cell in Isolated Islands. Journal of International Council on Electrical Engineering. 2(4): 423-429.

DOI: https://doi.org/10.5370/JICEE.2012.2.4.423.

[3] Hinds, G. and E. Brightman. 2012. In Situ Mapping of Electrode Potential in a PEM Fuel Cell. Electrochemistry Communications. 17 (2012): 26-29.

DOI: https://doi.org/10.1016/j.elecom.2012.01.007.

[4] Felseghi, R., E. Carcadea, M. Raboaca, C. Trufin, and C. Filote. 2019. Hydrogen Fuel Cell Technology for the Sustainable Future of Stationary Applications. Energies. 12: 4593.

DOI: $10.3390 /$ en 12234593.

[5] Cowey, K., K. Green, G. Mepsted. and R. Reeve. Portable and military fuel cells. 2004. Current Opinion in Solid State and Materials Science. 8(2004): 367-371.

DOI: https://doi.org/10.1016/j.cossms.2004.12.004.

[6] Patil, A., T. Dubois, N. Sifer, E. Bostic, K. Gardner, M. Quah. and C. Bolton. 2004. Portable Fuel Cell Systems for America's Army: Technology Transition to the Field. Journal of Power Sources. 136(2004): 220-225.

DOI: https://doi.org/10.1016/j.jpowsour.2004.03.009.

[7] Scataglini, R., M. Wei, A. Mayyas, S. H. Chan, T. Lipman, and M. Santarelli. 2017. A Direct Manufacturing Cost Model for Solid-Oxide Fuel Cell Stacks. Fuel Cells. 17(2017): 825-842.
DOI: https://doi.org/10.1002/fuce.201700012.

[8] Sharaf O. Z. and M. Orhan. 2014. An overview of fuel cell technology: Fundamentals and applications. Journal of Renewable and Sustainable Energy Reviews. 32(2014): 810-853.

DOI: https://doi.org/10.1016/j.rser.2014.01.012.

[9] Selamogullari, U. S., T. David, and Sheppard. S. 2010. A Systems Approach for a Stand-alone Residential Fuel Cell Power Inverter Design. IEEE Transactions on Energy Conversion. 25(3): 741-9.

DOI: 10.1109/TEC.2010.2047057

[10] Zoulias, E. I., and N. Lymberopoulus. 2007. Technoeconomic Analysis of the Integration of Hydrogen Energy Technologies in Renewable Energy-based Stand-alone Power Systems. Renewable Energy. 32(2007): 680-696. DOI: https://doi.org/10.1016/j.renene.2006.02.005.

[11] Wang, C., M. Nehrir, and H. Gao. Control of PEM Fuel Cell Distributed Generation Systems. 2006. IEEE Transactions On Energy Conversion. 21 (2): 586-95. DOI: https://doi.org/10.1109/TEC.2005.860404.

[12] Ryuji, Y., K. Nobuyuki, and M. Kazuaki. A 1 kW GridConnected Converter System for PEFC. Power Conversion Conference-Nagoya, 2007. PCC'07. IEEE; 2007. DOl: https://doi.org/10.1109/PCCON.2007.373006.

[13] Nelson, D. B., M. Nehrir, and C. Wang. 2005. Unit Sizing of Stand-alone Hybrid Wind/PV/Fuel Cell Power Generation Systems. Proceedings of IEEE Power Engineering Society General Meeting, 2005. IEEE; 2005. DOI: https://doi.org/10.1109/PES.2005.1489286

[14] Karakoulidis, K., D. Mavridis, P. Bandekas, C. Adoniadis, and P. Vordos. 2011. Techno-economic Analysis of a StandAlone Hybrid Photovoltaic-Diesel-Battery-Fuel Cell Power system. Renewable Energy. 36(8): 2238-44. DOI: https://doi.org/10.1016/j.renene.2010.12.003.

[15] Sammes, Nigel. B, Roberto. and S. Knut. 2004. Phosphoric Acid Fuel Cells: Fundamentals and Applications. Current Opinion in Solid State \& Materials Science. 2004: 372-378. DOI: https://doi.org/10.1016/j.cossms.2005.01.001.

[16] Nagamoto, H. 2001. Fuel Cells: Electrochemical Reactions. Elsevier. DOI: https://doi.org/10.1016/B0-08-043152-6/00600-8.

[17] Yamazaki, O., M. Echigo, N. Shinke, and T. Tabata. 2001. Development of Residential PEFC Cogeneration Systems at Osaka Gas. Proceedings of the Fuel Cell Home, Lucerne, Switzerland.

[18] Zhang, X. 2018. Current Status of Stationary Fuel Cells for Coal Power Generation. Clean Energy. 2: 126-139. DOI: https://doi.org/10.1093/ce/zky012.

[19] Plunkett. J. 2010. Plunkett's Automobile Industry Almanac 2011. Houston, TX: Plunkett Research.

[20] Wipke, K., S, Sprik, J. Kurtz, and T. Ramsden. 2010. Controlled Hydrogen Fleet and Infrastructure Analysis. National Renewable Energy Laboratory. DOI: https://doi.org/10.2172/15016868

[21] Das. H. S., T. Chee, and A. Yatim. 2017. Fuel Cell Hybrid Electric Vehicles: A Review on Power Conditioning Units and Topologies. Renewable and Sustainable Energy Reviews. 2017: 268-291. DOI: https://doi.org/10.1016/j.rser.2017.03.056

[22] Marshall, J. and M. Kazerani. 2005. Design of an Efficient Fuel Cell Vehicle Drivetrain, Featuring a Novel Boost Converter. Industrial Electronics Society, 2005. IECON 2005. Proceedings of the 3lst Annual Conference of IEEE. IEEE; 2005. DOI: https://doi.org/10.1109/IECON.2005.1569080

[23] Emadi, A. K. Rajashekara, S. Williamson, and S. Lukic, I. 2005. Topological Overview of Hybrid Electric and Fuel Cell Vehicular Power System Architectures and Configurations. IEEE Transactions on Vehicular Technology. 54(3): 763-70. DOI: https://doi.org/10.1109/TVT.2005.847445.

[24] Venturi M, C. Mohrdieck, and J. Friedrich. 2013. MercedesBenz b-class Fuel Cell: The World Largest Hydrogen Vehicle Fuel Cell Fleet Experience. Proceedings of Electric Vehicle Symposium and Exhibition (EVS27), 2013 World. IEEE; 2013. 
DOI: https://doi.org/10.1109/EVS.2013.6915019

[25] Ki, A. B., and T. Lim. 2006. Fuel Cell Vehicle Development at Hyundai-Kia Motors. Proceedings of the 1st international Forum on Strategic Technology, IEEE; 2006. DOI: https://doi.org/10.1109/IFOST.2006.312284.

[26] Shinji, A., K. Mikio, and Yasuhiro. A. 2007. Development of Fuel Cell Hybrid Vehicles in Toyota. Proceedings of PCC'07 Power Conversion Conference-Nagoya, 2007. IEEE; 2007. DOI: https://doi.org/10.1109/PCCON.2007.373179

[27] Blake. G. 2008. Solid Oxide Fuel Cell Development for Auxiliary Power in Heavy Duty Vehicle Applications. Delphi Corporation Fuel Cells and Reformers Product Team. Retrieved from: https://www.hydrogen.energy.gov/pdfs/progress10/v_i_2 shaffer.pdf.

[28] Brodrick, C., T, Lipman., M, Farshchi., N, Lutsey., H, Dwyer., D, Sperling., S, Gouse., Harris. D., G. Foy. and King, J. 2002. Evaluation of Fuel Cell Auxiliary Power Units for Heavy-duty Diesel Trucks. Transportation Research Part D: Transport Environment. 7(4): 303-315. DOI: https://doi.org/10.1016/\$1361-9209(01)00026-8

[29] Beckhaus, P., M, Dokupil. A, Heinzel. S, Souzani. and C. Spitta. 2005. On-board Fuel Cell Power Supply for Sailing Yachts. Journal of Power Sources. 145(2005): 639-43. DOI: https://doi.org/10.1016/j.jpowsour.2004.12.078.

[30] Agnolucci, P. 2007. Prospects of Fuel Cell Auxiliary Power Units in the Civil Markets. International Journal of Hydrogen Energy. 32(17): 4306-4318. DOI: https://doi.org/10.1016/j.jijhydene.2007.05.017.

[31] Henne, R. and K. Friedrich. 2009. Applications: Transportation: Auxiliary Power Units: Fuel Cells. In: Garche J, editor. Encyclopedia of Electrochemical Power Sources. Amsterdam: Elsevier.

[32] Lutsey, N., C. Brodrick, D. Sperling, and H. Dwyer. 2003. Markets for Fuel Cell Auxiliary Power Units in Vehicles: A Preliminary Assessment. Journal of the Transportation Research Board. 1842: $118-126$.

DOI: https://doi.org/10.3141\%2F1842-14

[33] Gaines, L., C. Hartman, and M. Solomon. 2009. Energy Use and Emissions Comparison of Idling Reduction Options for Heavy-duty Diesel Trucks. Transportation Research Record: Journal of the Transportation Research Board. 2123(1): 8-16. DOI: https://doi.org/10.3141\%2F2123-02.

[34] Qi, Z. 2009. Application: Transportation: Light Traction: Fuel Cells. In: Garche J, editor. Encyclopedia of Electrochemical Power Sources. Amsterdam: Elsevier.

[35] Dicks, A. 2012. PEM Fuel Cells: Applications. In: Sayigh A, editor. Comprehensive Renewable Energy. Oxford: Elsevier.

[36] Wang F.C. and Y. Chiang. 2012. Design and Control of a PEMFC Powered Electric Wheelchair. International Journa of Hydrogen Energy. 37: 11299-307.

DOI: https://doi.org/10.1016/j.jhydene.2012.04.156.

[37] Hwang, J, D. Wang, and N. Shih. 2005. Development of a Lightweight Fuel Cell Vehicle. Journal of Power Sources. 141: 108-15.

DOI: https://doi.org/10.1016/j.jpowsour.2004.08.056.

[38] Hochgraf, C. 2009. Application: Transportation: Electric Vehicles: Fuel Cells. In: Garche J, editor. Encyclopedia of Electrochemical Power Sources. Amsterdam: Elsevier.

[39] Alaswad, A., A. Baroutaji, H. Archour, J. Carton, A. Makky and A. Olabi. Developments in Fuel Cell Technologies in the Transport Sector. International Journal of Hydrogen Energy. 2016: 16499-16508.

DOI: https://doi.org/10.1016/j.jijhydene.2016.03.164.

[40] Campanari. S., G. Manzolini. and F. Garcia. 2009. Energy Analysis of Electric Vehicles Using Batteries or Fuel Cells through Well-to-Wheel Driving Cycle Simulations. Journal of Power Sources. 186: 464-77.

DOI: https://doi.org/10.1016/j.jpowsour.2008.09.115

[41] Thomas. C. 2009. Fuel Cell and Battery Electric Vehicles Compared. International Journal of Hydrogen Energy. 34(2009): 6005-20.

DOI: https://doi.org/10.1016/j.jhydene.2009.06.003.
[42] Ahluwalia, R., T. Hua, and J. Peng. 2012. On-board and offboard Performance of Hydrogen Storage Options for LightDuty Vehicles. International Journal of Hydrogen Energy. 37(2012): 2891-2910. DOl: https://doi.org/10.1016/j.jjhydene.2011.05.040.

[43] Eudy L, K. Chandler, and C. Gikakis. 2012. Fuel Cell Buses in U.S. Transit Fleets: Current Status 2012. National Renewable Energy Laboratory. NREL/TP-5600-56406; 2012.

[44] Ally, J. and T. Pryor. 2007. Life-cycle Assessment of Diesel, Natural Gas and Hydrogen Fuel Cell Bus Transportation Systems. Journal of Power Sources. 170(2007): 401-41 1. DOI: https://doi.org/10.1016/j.jpowsour.2007.04.036.

[45] Saxe, M., A. Folkesson, and P. Alvfors. 2008. Energy System Analysis of the Fuel Cell Buses Operated in the Project: Clean Urban Transport for Europe. Energy. 33(5): 689-71 1. DOI: https://doi.org/10.1016/j.energy.2008.01.001.

[46] Li, X., J. Li, L. Xu, F. Yan, J. Hua, and M. Ouyang. 2010. Performance Analysis of Proton-exchange Membrane Fuel Cell Stacks Used In Beijing Urban-route Buses Trial Project. International Journal of Hydrogen Energy. 35(2010): 38413847.

DOl: https://doi.org/10.1016/j.jjhydene.2010.01.097.

[47] Eudy. L. and K. Chandler. 2012. Zero Emission Bay Area (ZEBA) Fuel Cell Bus Demonstration: Second Results Report. National Renewable Energy Laboratory. Retrieved from: https://afdc.energy.gov/files/u/publication/zeba_fcb_rpt6 .pdf.

[48] Neves. N. and C. Pinto. 2013. Licensing a Fuel Cell Bus and a Hydrogen Fuelling Station in Brazil. International Journal of Hydrogen Energy. 38(2013): 8215-8220.

DOI: https://doi.org/10.1016/j.ijhydene.2013.01.035.

[49] Gao, D., Jin, Z., and Lu. Q. 2008. Energy Management Strategy Based on Fuzzy Logic for a Fuel Cell Hybrid Bus. Journal of Power Sources. 185(1): 311-317.

[50] Guo L, K. Yedavalli, and D. Zinger. 2011. Design and Modeling of Power System for a Fuel Cell Hybrid Switcher Locomotive. Energy Conversion and Management. 52: 1406-13. DOI: https://doi.org/10.1016/j.jpowsour.2008.06.083.

[51] Miller, A. R., J. Peters, B. Smith and E. Velev. 2006. Analysis of Fuel Cell Hybrid Locomotives. Journal of Power Sources. 157: 855-61.

DOI: 10.1016/j.jpowsour.2005.12.051

[52] Bradley, T., B. Moffitt, D. Mavris, and D. Parekh. 2009. Applications: Transportation: Aviation: Fuel Cells. In: Garche J, editor. Encyclopedia of Electrochemical Power Sources. Amsterdam: Elsevier.

[53] Kim, K., T. Kim, K. Lee and S. Kwon. 2011. Fuel Cell System with Sodium Borohydride as Hydrogen Source for Unmanned Aerial Vehicles. Journal Power Sources. 196(2011): 9069-75. DOI: https://doi.org/10.1080/15435075.2018.1464924.

[54] Uno $M$, Shimada T, Ariyama, Y, Fukuzawa N, Noguchi D, Ogawa K, H. Naito, Y. Sonea, and Y. Saitoa. 2009. Development and Demonstration Flight of a Fuel Cell System for High-altitude Balloons. Journal of Power Sources. 193: 788-96. DOI: https://doi.org/10.1016/j.jpowsour.2009.05.010.

[55] Sone, Y., Ueno, H. Naito, and S. Kuwajima. 2006. One kilowatt-class Fuel Cell System for the Aerospace Applications in a Micro-Gravitational and Closed Environment. Journal of Power Sources. 157(2006): 886-92. DOI: 10.1016/j.jpowsour.2006.03.042.

[56] Sone. Y., Ueno, M. and S. Kuwajima. 2004. Fuel Cell Development for Space Applications: Fuel Cell System in a Closed Environment. Journal of Power Sources. 137: 269-76. DOI: https://doi.org/10.1016/j.jpowsour.2004.03.051.

[57] Alkaner, S., and P. Zhou. 2006. A Comparative Study on Life Cycle Analysis of Molten Carbon Fuel Cells and Diesel Engines for Marine Application. Journal of Power Sources. 158: 188-99.

DOI: https://doi.org/10.1016/j.jpowsour.2005.07.076. 
[58] Leo, T. J., J. Durango, and E. Navarro. 2010. Exergy Analysis of PEM Fuel Cells for Marine Applications. Energy. 35(2): 1164-1171.

DOI: https://doi.org/10.1016/j.energy.2009.06.010.

[59] Romer Richard. 2011. Fuel Cell Systems Provide Clean Backup Power in Telecom Applications Worldwide. Proceedings of 2011 IEEE 33rd International Telecommunications Energy Conference (INTELEC), IEEE; 2011.

[60] Ross, D. 2009. Power Struggle: Power Supplies for Portable Equipment. IEE Review. 49(7): 34-38. DOI: 10.1049/ir:20030705.

[61] Petch, M., S. Burton, A. Hodgkinson, R.'Malley, \& Turner. W. 2015. Mitigation of Fuel Cell Degradation through MEA Design. SAE International Journal of Passenger CarsMechanical Systems. 9(1): 1-5. DOI: 10.4271/2015-01-1777.

[62] Zhang, C., and H. Zhao. 2012. Influence of in Content on the Electrical Conduction Behavior of Sm and In-co-doped Proton Conductor BaCe 0.80-xSm 0.20In xO 3-ס. Solid State Ionics. 206: 17-21. DOI: 10.1016/j.ssi.2011.10.026

[63] Xie. K., R. Yan, X. Chen, S, Wang, Y. Jiang, X. Liu, and G. Meng. 2009. A Stable and Easily Sintering Baceo3-Based Proton-Conductive Electrolyte. Journal of Alloys and Compound. 473(1-2): 323-9.

[64] Sawant, P. S. Varma, N. Wani, and S. Bharadwaj. 2012. Synthesis, Stability and Conductivity of BaCe0.8-xZrxY0.2O3$\delta$ as Electrolyte for Proton Conducting SOFC. International Journal of Hydrogen Energy. 37(4): 3848-56. DOI: https://doi.org/10.1016/j.ijhydene.2011.04.106.

[65] Shao, Y., J. Dodelet, G. Wu, \& P. Zelenay. 2019. PGM-Free Cathode Catalysts for PEM Fuel Cells: A Mini-Review on Stability Challenges. Advanced Materials. 31 (31): 1807615.
DOI: https://doi.org/10.1002/adma.201807615.

[66] Cai, L., Hu, S., Cao, Z., Li, H., Zhu, X., and Yang, W. 2019. Dual-phase Membrane Reactor for Hydrogen Separation with High Tolerance to $\mathrm{CO}_{2}$ and $\mathrm{H}_{2} \mathrm{~S}$ Impurities. AlChE Journal. 65(3): 1088-1096. DOI: https://doi.org/10.1002/aic.16491.

[67] Mahdavi, A., Ranjbar, A. A., Gorji, M., and Rahimi-Esbo, M. 2018. Numerical Simulation Based Design for an Innovative PEMFC Cooling Flow Field with Metallic Bipolar Plates. Applied Energy. 228: 656-666.

[68] Barbier, E. B. 2007. Natural Resources and Economic Development. Cambridge University Press.

[69] Gylfason, T. 2001. Natural Resources, Education, and Economic Development. European Economic Review. 45(4-6): 847-859.

[70] O'hayre, R., Cha, S. W., Colella, W., and Prinz, F. B. 2016. Fuel Cell Fundamentals. John Wiley \& Sons.

[71] Larminie, J., Dicks, A., and McDonald, M. S. 2003. Fuel Cell Systems Explained. 2: 207-225. Chichester, UK: J. Wiley.

[72] Basu, S. 2007. Fuel Cell Science and Technology. Anamaya Publishers, New Delhi, India. 188- 215.

[73] Yilmaz, E., and Ispirli, M. 2015. An Investigation on the Parameters that Affect the Performance of Hydrogen Fuel Cell. Procedia-Social and Behavioral Sciences.195: 23632369.

[74] Chopra, A. and Gupta, A. 2019. Fuel Cell Market Size by Product (PEMFC, DMFC, SOFC), By Application (Stationary, Portable, Transport), Industry Analysis Report, Regional Outlook, Application Potential, Competitive Market Share \& Forecast, 2020 - 2026. Global Market Insights. 